\title{
ПРОБЛЕМИ МЕТОДИКИ НАВЧАННЯ МОВ І ЛІТЕРАТУР НАЦІОНАЛЬНИХ МЕНШИН
}

Наукова доповідь на засіданні Президії НАПН України 20 травня 2021 р. https://doi.org/10.37472/2707-305X-2021-3-1-2-7

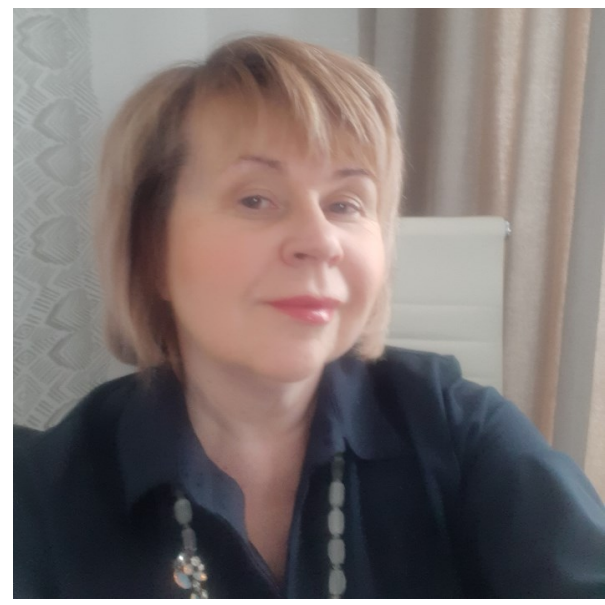

\section{ФІДКЕВИЧ Олена Львівна}

кандидат фрілологічних наук, провідний науковий співробітник відділу навчання мов національних меншин і зарубінної літератури Інституту педагогіки Начіональної академії педагогічних наук України, м. Київ, Україна

\section{Наталія Валеріївна БАКУЛІНА} кандидат педагогічних наук, старший науковий співробітник відділу навчання мов начіональних меншин і зарубіжної літератури Інституту педагогіки Начіональної академії педагогічних наук України, м. Київ, Україна
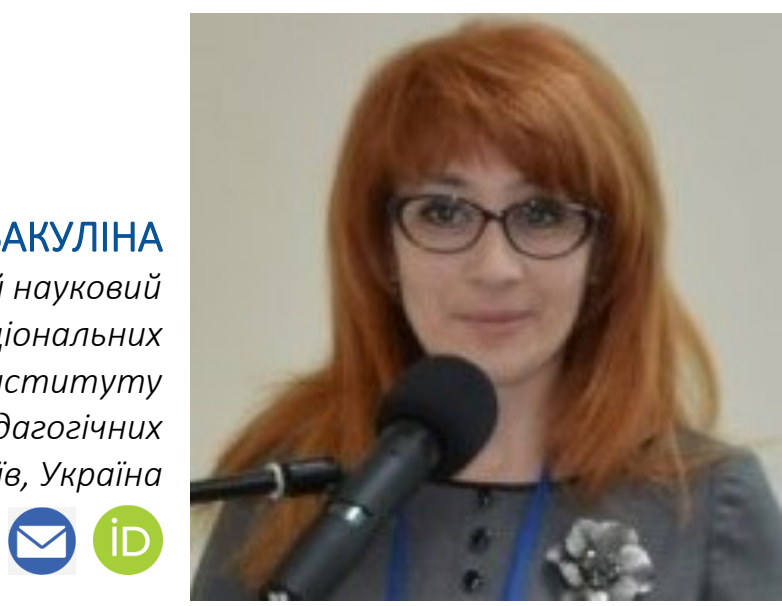

Анотація. У доповіді висвітлено основні результати наукового дослідження «Методика компетентнісно орієнтованого навчання мов і літератур національних меншин у ліцеї», що здійснювалося впродовж 20182020 рр. науковими співробітниками підрозділу відділу навчання мов національних меншин і зарубіжної літератури Інституту педагогіки Національної академії педагогічних наук України. Презентовано визначені й обгрунтовані науково-методичні засади компетентнісно орієнтованого навчання мов $і$ літератур національних меншин у ліцеї; уперше розроблені методики компетентнісно орієнтованого навчання інтегрованого курсу російської мови та літератури в ліцеї, компетентнісно орієнтованого навчання новогрецької мови і літератури на основі роботи з культурологічними текстами, роботи з культурологічними текстами в процесі компетентнісно орієнтованого навчання мови іврит, компетентнісно орієнтованого навчання ромської мови в школі; концептуальні засади конструювання компетентнісно орієнтованих підручників інтегрованого курсу російської мови та літератури, навчальнометодичного посібника з навчання мови іврит, практичного посібника з навчання новогрецької мови $і$ літератури та методичного посібника з навчання ромської мови, сформовано та структуровано їхній навчальний зміст, розроблено методичний апарат; представлено наукову, виробничо-практичну та навчальну продукцію, створену науковими співробітниками за темою дослідження, на виконання невідкладних завдань реформування української школи, Програми спільної діяльності Міністерства освіти і науки України та Національної академії педагогічних наук України, співпраці з міжнародними партнерами й організаціями, методичної допомоги освітянам в умовах дистанційного та змішаного навчання; визначено перспективні напрями роботи.

Ключові слова: методики навчання; компетентнісно орієнтоване навчання; мови і літератури національних меншин; проблеми та результати дослідження. 
Питання розвитку мов національних меншин у контексті реформування української освіти набувають особливого значення, враховуючи багатонаціональний склад нашої держави та необхідність громадянського об'єднання всіх їі національностей навколо вирішення важливого завдання - модернізації та подальшої розбудови України.

Зазначимо, що у закладах освіти України освітній процес здійснюється не лише державною мовою, а й 9 мовами національних меншин. Як предмет вивчається 31 мова, зокрема 19 мов національних меншин. Тому проблеми забезпечення високої якості навчання мов і літератур національних меншин перебувають у центрі уваги відділу навчання мов національних меншин і зарубіжної літератури Інституту педагогіки Національної академії педагогічних наук України.

у 2018-2020 рр. наукові співробітники підрозділу зазначеного відділу працювали над прикладним дослідженням: «Методика компетентнісно орієнтованого навчання мов і літератур національних меншин у ліцеї» (керівник - канд. філол. наук О.Л. Фідкевич). Дослідження здійснювали 7 співробітників відділу, серед них 4 кандидати наук, 3 наукові співробітники без ступеня. Дослідження мало чітко виражений прикладний характер і спрямовано на забезпечення наукового та навчально-методичного супроводу реформування шкільної мовно-літературної освіти, зокрема навчання мов і літератур національних меншин.

У процесі виконання дослідження визначено й обґрунтовано науково-методичні засади компетентнісно орієнтованого навчання мов і літератур національних меншин у ліцеї, зокрема:

- особливості й умови застосування інтегративного, комунікативно-когнітивного, особистіснодіяльнісного, культурологічного, текстоцентричного підходів;

- реалізацію методу комплексного та порівняльного аналізу текстів у процесі навчання мов і літератур національних меншин з метою формування ключових і предметних компетентностей учнів ліцею.

Уперше в Україні розроблено:

- методику компетентнісно орієнтованого навчання інтегрованого курсу російської мови та літератури в ліцеї;

- методику компетентнісно орієнтованого навчання новогрецької мови і літератури на основі роботи з культурологічними текстами;

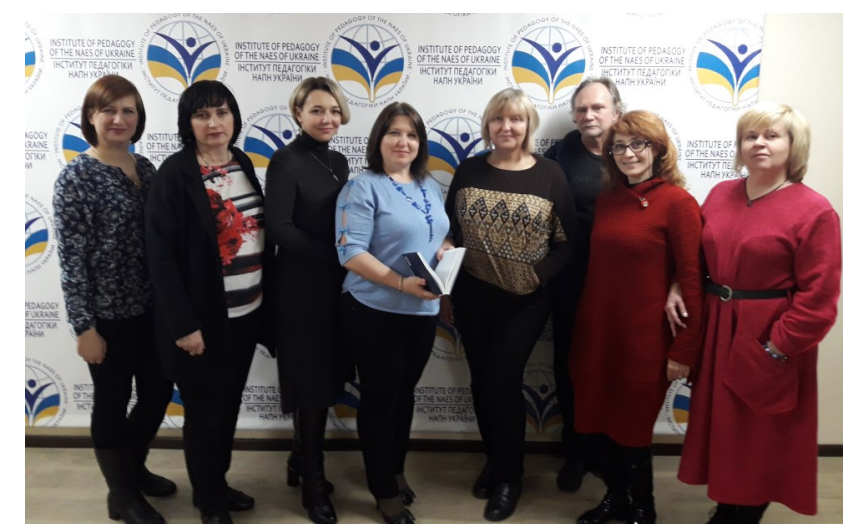

- методику роботи з культурологічними текстами в процесі компетентнісно орієнтованого навчання мови іврит;

- методику компетентнісно орієнтованого навчання ромської мови в школі.

Визначено концептуальні засади конструювання компетентнісно орієнтованих підручників інтегрованого курсу російської мови та літератури, навчально-методичного посібника з навчання мови іврит, практичного посібника з навчання новогрецької мови і літератури та методичного посібника з навчання ромської мови; сформовано та структуровано їхній навчальний зміст, розроблено методичний апарат. Такі напрями дослідження пояснюються об'єктивними причинами: поперше, наявністю відповідних фахівців, по-друге, тим, що методика навчання кожної із цих мов може слугувати методологічним підґрунтям розроблення методик навчання інших мов національних меншин.

За результатами дослідження підготовлено й видрукувано 2 підручники з інтегрованого курсу російської мови і літератури для 10 і 11 класів (надано гриф МОН України) відповідно до створеної співробітниками відділу навчальної програми цього курсу. Підготовлено та рекомендовано до друку вченою радою Інституту педагогіки НАПН України рукописи: навчально-методичного посібника «Методика роботи з культурологічними текстами на уроках мови іврит у ліцеї» (Н.В. Бакуліна); практичного посібника «Методика

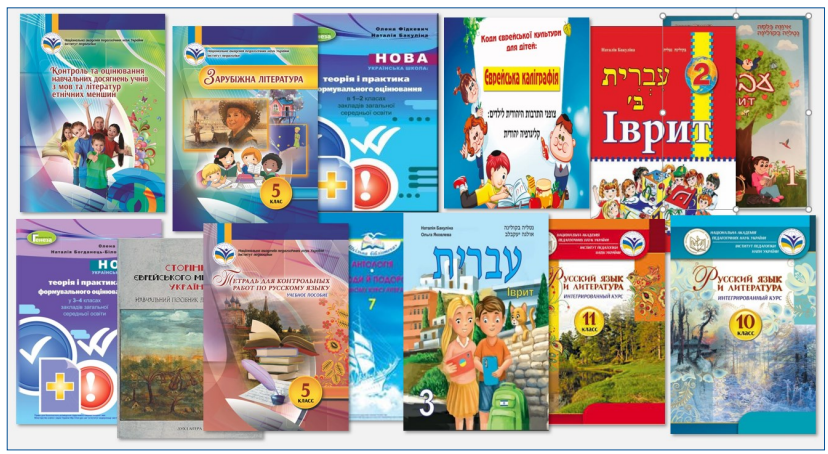


компетентнісно орієнтованого навчання новогрецької мови і літератури: робота з культурологічними текстами в 10-11 класах» (Є.К. Чєрнухін); методичного посібника «Методика компетентнісно орієнтованого навчання ромської мови в школі» (3.А. Кондур ).

Розроблено критерії оцінювання навчальних досягнень учнів з інтегрованого курсу російської мови і літератури, підготовлено методичні рекомендації до підручників інтегрованого курсу «Російська мова і література» та календарне планування для вчителів.

Результати дослідження також представлено у 18 статтях, 66 тезах, надрукованих у збірниках матеріалів конференцій, семінарів, форумів. Вони пройшли апробацію в експериментальних закладах освіти, з якими укладено відповідні угоди, а також під час виступів на конференціях, семінарах, круглих столах.

Упродовж 2018-2020 рр. співробітники відділу взяли участь у 67 заходах, із них - 39 міжнародних. Усі матеріали розміщено в електронних бібліотеках НАПН України й Інституту педагогіки НАПН України, прес-релізи й анонси оприлюднено на сайті Інституту та Фейсбук-сторінці відділу.

Вченими відділу також створено продукцію на виконання невідкладних завдань реформування української школи:

- 4 навчальні програми («Мова іврит. 1-2 класи» і «Мова іврит. 3-4 класи»; «Зарубіжна література. 10-11 класи», «Російська мова і література. Інтегрований курс. 8 клас»);

- науково-методичні посібники «Нова українська школа: теорія і практика формувального оцінювання у 1-2 класах закладів загальної середньої освіти», "Нова українська школа: теорія і практика формувального оцінювання у 3-4 класах закладів загальної середньої освіти»;

- хрестоматію «Антологія. Пригоди і подорожі в шкільному курсі літератури: посібник серії «Шкільна бібліотека» для 7 класу закладів загальної середньої освіти»;

- підручники з мови іврит для 1, 2 і 3 класу початкової школи та робочий зошит із зарубіжної літератури для 5 класу.

Уся ця продукція отримала гриф МОН України і надрукована державним коштом за результатами конкурсного відбору.

У межах виконання Програми спільної діяльності Міністерства освіти і науки України та Національної академії педагогічних наук України на

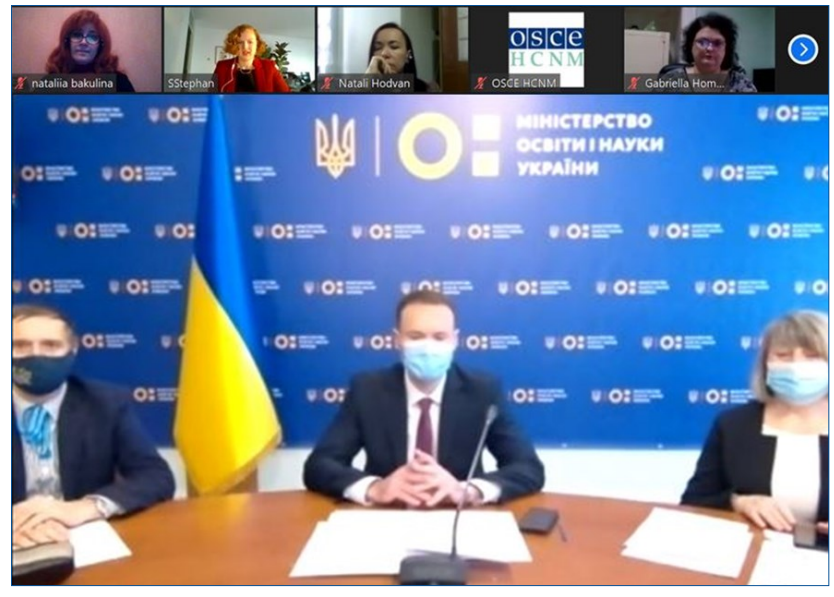

2018-2020 рр. наукові співробітники відділу брали участь:

- у розробленні типового навчального плану та модельних програм;

- в експертизі рукописів підручників, посібників з мов національних меншин, навчальних програм, методичних посібників для вчителів, що подаються до науково-методичної комісії науково-методичної ради МОН України з метою отримання відповідного грифу;

- працювали також у складі журі всеукраїнських олімпіад з мов національних меншин.

Співробітники відділу О.Л. Фідкевич і Н.В. Бакуліна з 2016 р. співпрацюють з офісом Верховного комісара ОБСЕ у справах національних меншин і беруть участь у всеукраїнському експерименті «Формування багатомовності дітей та учнів: прогресивні європейські ідеї в українському контексті», що проводиться за підтримки Міністерства освіти і науки України та ОВК ОБСЕ у справах національних меншин. О.Л. Фідкевич $€$ науковим консультантом цього експерименту (наказ $\mathrm{MOH}$ України «Про проведення дослідноекспериментальної роботи на базі дошкільних та загальноосвітніх навчальних закладів Закарпатської, Одеської та Чернівецької областей» від 8 лютого 2016 р. № 95). У 2020 р. за результатами експерименту видано науково-методичний посібник за підтримки МОН України і ОВК ОБСЕ у справах національних меншин «Успішні практики багатомовної освіти в Україні», у якому вміщено матеріали, підготовлені співробітниками відділу. У травні 2020 р. О.Л. Фідкевич і Н.В. Бакуліну включено до реєстру експертів офісу Верховного комісара ОБСЄ у справах національних меншин для подальшої співпраці.

Відділ співпрацює з Офісом Ради Європи в Україні у вирішенні проблеми кодифікації ромської 


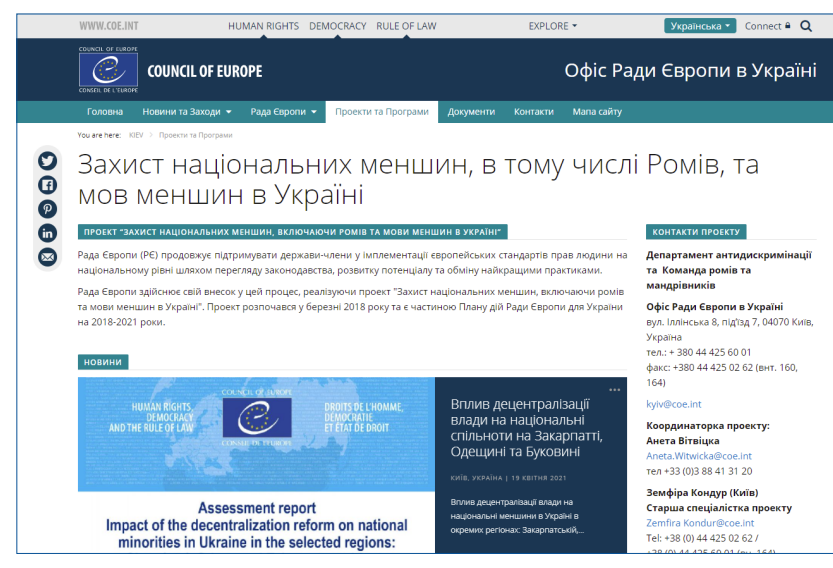

мови в рамках проєкту Ради Європи «Захист національних меншин, включаючи ромів та мови меншин в Україні» за ініціативи та підтримки Міністерства освіти і науки України спільно з Офісом Ради Європи в Україні (3.А. Кондур - співорганізатор проєкту).

Н.В.Бакуліна $\epsilon$ заступницею голови Ради представників громадських об'єднань корінних народів, національних меншин України при Міністерстві освіти і науки України (з 2018 р.); співробітники відділу беруть участь у засіданнях Ради й обговоренні проблем у галузі освіти корінних народів і національних меншин.

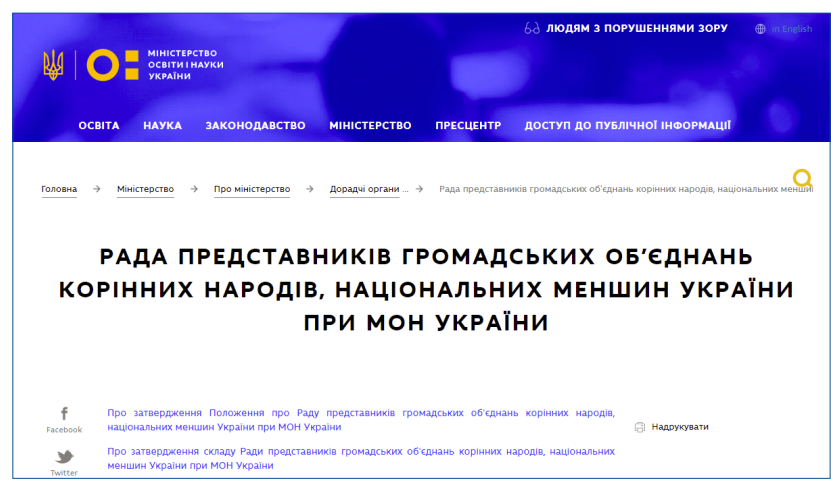

у соціальній мережі Фейсбук створено групу «Відділ навчання мов національних меншин і зарубіжної літератури».

Учені відділу активно долучалися до надання методичної допомоги вчителям з організації дистанційного навчання в умовах карантину. Проведено 7 онлайн-тренінгів, присвячених орга-нізації дистанційного навчання української мови, мов національних меншин і зарубіжної літератури, опубліковано низку статей з цієї проблеми. У посібнику «Нова українська школа: формувальне оцінювання у 3-4 класах початкової школи» виокремлено розділ «Формувальне оцінювання в умовах дистанційного навчання».

Щороку вчені відділу готують і видають методичні рекомендації щодо вивчення в закладах загальної середньої освіти української мови та літератури, а також мов і літератур національних меншин і зарубіжної літератури. Надається методична допомога вчителям-мовникам із запровадження дистанційних форм навчання, формувального оцінювання.

3 метою вивчення стану вирішення проблеми запровадження дистанційного навчання в умовах карантину, спричиненого пандемією COVID-19, співробітниками відділу були проведені онлайн інтерв'ю, опитування вчителів та експертне оцінювання їхньої практичної діяльності на різних етапах здійснення дистанційного навчання мов національних меншин. Це дало змогу виявити актуальні психолого-педагогічні, лінгводидактичні та методологічні проблеми організації й упровадження дистанційного навчання. Результати цього позапланового дослідження було представлено в статтях, тезах, доповідях на науковометодичних конференціях, які розміщено в електронній бібліотеці Інституту педагогіки НАПН України.

У перспективі наукові співробітники відділу навчання мов національних меншин і зарубіжної літератури Інституту педагогіки НАПН України працюватимуть над вирішенням таких питань:

- створення моделі багатомовної освіти в закладах загальної середньої освіти України з навчанням мов корінних народів та національних меншин і розроблення науково-методичного забезпечення її реалізації;

- реалізація основних положень нового Державного стандарту базової середньої освіти;

- розроблення методики навчання інтегрованих курсів мов і літератур національних меншин в середній ланці освіти;

- кодифікація ромської мови та підготовка навчальних програм з ромської мови для початкової школи;

- удосконалення технології формувального оцінювання та визначення критеріїв оцінювання навчальних досягнень учнів в умовах мовнолітературної інтеграції.

\section{СПИСОК ВИКОРИСТАНИХ ДЖЕРЕЛ}

Бакуліна, Н. (2019). Іврит : підручник для 2 класу закладів загальної середньої освіти. Чернівці: Букрек. https://lib.iitta.gov.ua/717034/

Бакуліна, Н., \& Гехтман, Р. (2020). Коди єврейської культури для дітей: Єврейська каліграфія : робочий зошит для навчання й удосконалення каліграфічної компетентності. Чернівці: «АНТ ЛТД». https:// lib.iitta.gov.ua/724601/ 
Бакуліна, Н., \& Фалеса, І. (2018). Іврит : підручник для 1 класу закладів загальної середньої освіти з навчанням українською мовою. Чернівці: Букрек. https://lib.iitta.gov.ua/712064/

Бакуліна, Н.В. (2009). Дистанційне навчання мови іврит: до постановки проблеми. In Технології інтелектуальної діяльності : тези доповідей міждисциплінарної науково-практичної конференції. https://lib.iitta.gov.ua/705858/

Бакуліна, Н.В. (2019). «Єврейський інтерактив» інноваційна освітня платформа електронного навчання мови іврит і предметів юдаїки. In Реалізація компетентнісно орієнтованого навчання в освіmi: теоретичні і практичні аспекти : збірник тез науково-практичної конференції (с. 40-42). Київ: Педагогічна думка. https://lib.iitta.gov.ua/719432/

Бакуліна, Н.В. (2020). Ефективні інструменти впровадження дистанційного навчання у глобалізованому світі. In О.І. Локшина (ред.), Педагогічна компаративістика і міжнародна освіта - 2020: глобалізований простір інновацій : матеріали IV Міжнародної науково-практичної конференції (с. 53-55). Київ, Біла Церква: Авторитет https:// lib.iitta.gov.ua/721042/

Бакуліна, Н.В. (2020). Застосування інноваційних технологій у дистанційному навчанні предметів юдаїки. In Сучасні виклики і актуальні проблеми науки, освіти та виробництва: міжгалузеві диспути : матеріали V Міжнародної науково-практичної інтернетконференції (с. 159-172). https://lib.iitta.gov.ua/720834/

Бакуліна, Н.В. (2020). Результати онлайн опитування вчителів «Потреби, пріоритети та досвід упровадження дистанційного навчання предметів юдаїки у З3СО України». In Сучасні виклики і актуальні проблеми науки, освіти та виробництва: міжгалузеві диспути : матеріали V Міжнародної науково-практичної інтернет-конференції (с. 86-102). https://lib.iitta.gov.ua/721190/

Бакуліна, Н.В., \& Фалеса, І.Ю. (2018). Типова навчальна програма з мови іврит для 1-2 класів закладів загальної середньої освіти. https:// lib.iitta.gov.ua/713374/

Бакуліна, Н.В., \& Фалеса, І.Ю. (2019). Навчальна програма з мови іврит та читання для 3-4 класів закладів загальної середньої освіти з навчанням українською мовою. https://lib.iitta.gov.ua/717428/

Бакуліна, Н.В., \& Яковлева, О.М. (2020). Іврит : підручник для 3 класу закладів загальної середньої освіти. Чернівці: Букрек. http://undip.org.ua/news/ library/pidruchniki_detail.php?ID=9960

Богданець-Білоскаленко, Н., \& Фідкевич, О. (упор.). (2020). Антологія. Пригоди і подорожі в шкільному курсі літератури : посібник серії «Шкільна бібліотека» для 7 класу закладів загальної середньої освіти. Київ: Грамота. https://cutt.ly/mmewPas

Відділ навчання мов національних меншин і зарубіжної літератури. (n.d.). Обговорення [Facebook Group]. Facebook. https://www.facebook.com/ groups/203301720967734

Електронна бібліотека НАПН України. (2005-2021). Відділ навчання мов національних меншин та зарубіжної лimeратури Iнституту педагогіки НАПН України. https://lib.iitta.gov.ua/view/divisions/rlloem/
Інститут педагогіки НАПН України. (n.d.). Відділ навчання мов національних меншин та зарубіжної літеpamypu. https://cutt.ly/HmeqReY

Інститут педагогіки НАПН України. (n.d.). Електронна бібліотека. http://undip.org.ua/news/library/

Кремень, В.Г., Луговий, В.І., Топузов, О.М., Регейло, І.Ю., \& Базелюк, Н.В. (2020). Про виконання Програми спільної діяльності Міністерства освіти і науки України та Національної академії педагогічних наук України на 2017-2020 роки. Вісник Національної академії педагогічних наук України, 2(2). https://doi.org/10.37472/2707-305X-2020-2-2-2-3

Міністерство освіти і науки України. (n.d.). Рада представників громадських об'єднань корінних народів, національних меншин України при МОН УкраїHu. https://mon.gov.ua/ua/ministerstvo/proministerstvo/doradchi-organi/rada-predstavnikivgromadskih-obyednan-korinnih-narodiv-nacionalnihmenshin-ukrayini-pri-mon-ukrayini

Офіс Ради Європи в Україні. (n.d.). Проект «Захист національних меншин, в тому числі Ромів, та мов меншин в Україні». https://www.coe.int/uk/web/ kyiv/national-minorities

Панченкова, А.О. (ред.). (2020). Успішні практики ба гатомовної освіти в Україні : науково-методичний посібник. Київ: Ваіте.

Снегірьова, В.В. (2018). Зарубіжна література. 5 клас : підручник. Київ: КОНВІ ПРІНТ. https:// lib.iitta.gov.ua/712553/

Топузов, О.М., Засєкіна, Т.М., \& Снєгірьова, В.В. (уклад.). (2018). Зарубіжна література : Нові навчальні програми для 10-11 класів закладів загальної середньої освіти (рівень стандарту, профільний рівень); Методичні коментарі провідних науковців Інституту педагогіки НАПН України. Київ: УОВЦ «Оріон». https://lib.iitta.gov.ua/714945/

Фідкевич, О., \& Богданець-Білоскаленко, Н. (2020). Нова українська школа: теорія і практика формувального оцінювання у 3-4 класах закладів загальної середньої освіти : навчально-методичний посібник. Київ: Генеза. https://lib.imzo.gov.ua/navchalnometodichn-posbniki/dlya-pedagogchnikhpratsvnikv/20201005/

Фідкевич, О.Л., \& Бакуліна, Н.В. (2019). Нова українська школа: теорія і практика формувального оцінювання у 1-2 класах закладів загальної середньої освіти : навчально-методичний посібник. Київ: Генеза. https://lib.iitta.gov.ua/718165/

Фідкевич, О.Л., \& Снєгірьова, В.В. (2020). Програма «Російська мова і література. Інтегрований курс. 8 клас».

Фідкевич, О.Л., Снєгірьова, В.В., \& Курач, Л.І. (2019). Російська мова і література. Інтегрований курс. 10 клас : підручник. Київ: КОНВІ ПРІНТ. https:// lib.iitta.gov.ua/718313/

Фідкевич, О.Л., Снєгірьова, В.В., \& Курач, Л.І. (2019). Російська мова і література. Інтегрований курс. 11 клас : підручник. Київ: КОНВІ ПРІНТ. https:// lib.iitta.gov.ua/718520/

Bakulina, N.V. (2020). Long-distance learning in the globalized world: contemporary tendencies and experience of implementation. Ukrainian Educational Journal, (3), 24-39. https://doi.org/10.32405/2411-13172020-3-24-39 


\section{PROBLEMS OF LANGUAGES AND LITERATURES OF NATIONAL MINORITIES TEACHING METHODS}

Scientific report at the meeting of the Presidium of the National

Academy of Educational Sciences of Ukraine, May 20, 2021

\section{Olena Fidkevych}

PhD in Philology, Leading Research Fellow of the Department of Teaching National Minority Languages and Foreign Literature, Institute of Pedagogy of the National Academy of Educational Sciences of Ukraine, Kyiv, Ukraine

Nataliia Bakulina

PhD in Pedagogy, Senior Research Fellow of the Department of Teaching National Minority Languages and Foreign Literature, Institute of Pedagogy of the National Academy of Educational Sciences of Ukraine, Kyiv, Ukraine

Abstract. The main research results on the methods of competence-oriented teaching languages and literatures of national minorities in the lyceum are enlightened in the report; the researchers of the Department of Teaching National Minority Languages and Foreign Literature at the Institute of Pedagogy of the National Academy of Educational Sciences of Ukraine conducted the study during 2018-2020. The defined and grounded scientific and methodological bases of competence-oriented teaching languages and literatures of national minorities in the lyceum are presented; the methods of competence-oriented teaching the integrated course of Russian language and literature in the lyceum, competence-oriented teaching the Modern Greek language and literature based on work with culturological texts, the work with culturological texts during competence-oriented teaching Hebrew, competence-oriented teaching Romani at school are developed for the first time; conceptual principles of designing competence-oriented textbooks for the integrated course of Russian language and literature, training and methodological manual for teaching Hebrew, practical manual for teaching the Modern Greek language and literature, and methodological manual for teaching Romani, their educational content is designed and structured, the methodological apparatus is developed; the scientific, practical and training publications are presented, prepared by the Department's researchers, to fulfill the urgent tasks of reforming the Ukrainian school, the Joint Activity Program of the Ministry of Education and Science of Ukraine and National Academy of Educational Sciences of Ukraine, collaboration with international partners and organizations, methodological assistance to teachers in distance and blended learning are presented; promising areas of work are identified.

Keywords: teaching methods; competence-oriented learning; languages and literatures of national minorities; research problems and results. 